\title{
Constructing a Career: Women Architects at Work
}

\author{
Dr Val Caven \\ Dept of Human Resource Management \\ Nottingham Business School \\ Nottingham Trent University \\ Nottingham \\ NG1 4BU \\ England \\ Tel: +44 (0) 1158484233 \\ Fax: + 44 (0) 1158486512 \\ E-mail: valerie.caven@ntu.ac.uk
}

Dr. Val Caven is Senior Lecturer in HRM at Nottingham Business School. Her research interests include work orientations and professional employment particularly women in male-dominated professions. She has recently begun work on men's work orientations and careers. 


\title{
Constructing a Career: Women Architects at Work
}

\begin{abstract}
Using data from 37 interviews carried out with female architects in Britain, this paper examines how they have constructed their careers in a male-dominated profession. The findings indicate that there is a significant rejection of the 'traditional' career within an organisation, instead there is diversity in the forms of work organisation adopted especially with regard to the desire for control over career and working life.
\end{abstract}

\section{Keywords}

Women's careers; self-employment; orientations to work; professional employment

Total word count: 6102 (including references and table)

\section{Introduction}

Over the last decade or so the notion of what constitutes a career has been called into question. The traditional employment security and upward progression associated with a career have been eroded and coupled with the growth in flexible forms of working are causing the concept of the term 'career' to be questioned. Recently it has been argued that the notion of the 'traditional' career as in the upward progression through an organisational or occupational hierarchy is no longer relevant (Young and Collin 2000) and that it must be considered in a boundaryless sense (Arthur and Rousseau, 1996).

In addition, women's commitment to their career has always been under scrutiny because they are not always able to follow the 'traditional' model of an unbroken, linear career path. Their careers have been judged against those of men which are not 
necessarily relevant (Shaw et al 2000). This paper examines the working lives of 37 women architects in the context of what constitutes a career and argues that there has been an over reliance on structural explanations to illustrate and justify women's employment without work being done to investigate women's own evaluations of their employment. More than half of those interviewed had taken control of their own career by adopting forms of working arrangements at variance to what is considered 'normal'. This paper argues that preferences regarding the level of involvement in a career are not predetermined and static and also that the career is subject to ongoing change in response to a number of intrinsic and extrinsic factors throughout its life cycle.

\section{Women and professional career}

The topic of women's orientations and commitment to their career has generated an abundance of literature throughout the 1990s, principally by Hakim (1996, 1998, 2000) but with additional contributions and responses by a variety of others (Crompton and Le Feuvre, 1996; Caven, 1999; Crompton and Harris, 1998; Ginn et al, 1996; Bruegel, 1996; Walsh, 1999; Procter and Padfield, 1999). Hakim (2000) has identified three distinct preferences held by women regarding their career: 'home-centred', 'adaptive' and 'work-centred'. The central tenet among these typologies is that women adapt their preferences according to whether they want to give priority to career or non-work rather than adapting their career to suit their lives. There is the underlying assumption that the notion of what constitutes a career is static and cannot be adapted. However, Young and Collin (2000) argue that changes in society are contributing to a change in the construction of a career and that the concept of continuity within a career is no longer 
relevant. This is supported by Patton who states that "more recent definitions [of career] emphasise that individuals must review their perception of career as an individual rather than an organisation phenomenon” (Patton, 2000:69).

Indeed, the 'boundaryless' career (Arthur and Rousseau 1996) emphasises the move away from dependence on an organisational setting for the career. This causes difficulties when applied to professional work which demands a certain level of commitment not required by other occupations with lower level entry qualifications (Hakim, 1995, 1996) and tends to translate into longer working hours (Epstein et a,l 1999). There are few professions in which part-time work or any deviation from the 'traditional' working patterns is commonplace in spite of many commentators suggesting that the flexible patterns of working adopted by women could be advantageous and applicable in a much wider context (Sullivan, 1999; Mallon and Cohen, 2001; Shaw et al, 2000).

\section{Women in the architecture profession}

Context: The architecture profession generally is a neglected area, previous studies on women in the profession have focussed on the historical background (Walker 1989) or why women leave (Adams and Tancred 2000; de Graft-Johnson et al 2003) giving the perception that it is not a desirable occupation. This study aims to redress the balance by giving women's observations of how they have constructed their careers in architecture, what made them choose the profession and how they have progressed since qualification. 
Historical background: In architecture, women were originally involved in an amateur philanthropic role (Walker, 1989). Designing social housing for estate workers was seen as a suitable past-time for an upper class lady but as the construction process moved away from its craft origins and became industrialised, it was considered to have developed in to a 'masculine' profession. Towards the end of the nineteenth century the most a woman was allowed to do was to trace plans and write specifications. This did at least allow some form of personal and financial independence but the work was of very low prestige and mundane. At the time it was seen as making use of women's natural skills in that it was demanding and required high attention to detail (Walker, 1989). At the time there was a further structural barrier of the marriage bar to employment which meant that only unmarried women could undertake this form of employment, having to give up paid employment upon marriage.

However, women continued to practise architecture in spite of the exclusionary tactics adopted by the profession, the 1891 census shows that there were nineteen women architects in England and Wales and a further five in Scotland (Walker 1989) even though they had not yet gained RIBA membership. It was 1898 before the first woman applied for RIBA membership, which was initially refused on the grounds that it would be prejudicial to the interests of the Institute. Many women who were in architecture at the start of this century were quite wellknown (Franz 1965), if only because their low numbers made them highly visible. Melvin (1997) reports that the formation of the RIBA did nothing to help the position of women architects because it reinforced and entrenched the inequalities which were present. 
Women in Architecture Today: There are approximately 32,000 architects registered with ARB (Architects Registration Board), of which 25,200 are employed (Source: ARB Register and Annual RIBA Survey of Registered Architects 2003). The remainder are unemployed or are not working for other reasons. Approximately $13 \%$ of the overall total is female and $11 \%$ of the profession is working part-time (Young 2003), this does not mean to say that it is mainly women are working part-time because there is a fairly strong tradition within the profession that as an architect nears retirement age, they are retained on a part-time consultancy basis. The figure may also include male architects working for local authorities where flexible working schemes such as jobsharing are offered. A further 13\% of the profession is classed as fully retired but many members retain membership of the RIBA and remain registered with the ARB.

Architectural education: The minimum time of studying and professional practice prior to qualification is seven years and comprises undergraduate study of three years in one of the 39 Schools of Architecture in the UK, one year spent in an architectural practice, a further two-year time spent studying for a post-graduate qualification or Masters degree followed by an additional one-year period of professional practice prior to qualification. In 1998, 31\% of undergraduates studying architecture were female but less than half progressed to the post-graduate qualification (Lewis 1998).

\section{Method}

The Participants: The sample was selected from the East Midlands region of the RIBA, as it comprises a variety of different contexts for employment within the 
profession with large urban practices (national and international) as well as small local practices numbering 180 in total and employing almost 1000 members (Source: RIBA 2003). Of these members, only 49 are women (significantly fewer than the national average of 11\%) and all were contacted by mail and 37 agreed to take part in the research. Their ages ranged from 27 to 72 (the eldest was retired) and all except one had begun the route to qualification immediately after finishing school, the late entrant had originally worked, albeit in a related sense, as a draughtswoman for a large contractor and began studying in her early thirties.

The research instrument and procedure: In-depth biographical interviews were carried out by the researcher with each of the women in a variety of locations including homes, offices, and cafes. The intention was to explore their career stories and to draw out the ways in which their careers had evolved. The interviews explored why the respondents chose architecture; where they studied and length of time taken to qualify; how their career had developed since qualification; the highlights and low points of their career; the pressures and satisfactions; the rewards both intrinsic and extrinsic; and, the factors which may have helped or hindered the career. The subject areas were not designed to be specifically question and answer type topics but areas for discussion. The lives and careers of the women interviewed showed so much diversity that it was not possible to construct an inflexible series of questions that all would be asked.

The semi-structured nature of the interviews provided a means for probing further depending upon the individual circumstances of the interviewee. This flexibility proved 
invaluable in establishing a rapport between interviewer and interviewee and as a result considerably enriched the data collected.

Analysis: All the interviews were taped and then transcribed. NUD.IST qualitative research software was used to help with the sorting and coding of the data for analysis. Initial coding was based on the interview schedule but emergent themes were explored and coded accordingly. This helps in the sense-making process of eliciting the meaning to the individual and how they consider their career and their lives in retrospect (Nicholson and West 1989). It is these themes which are examined in more depth in the sections which follow.

\section{Constructing a career}

At the time of being interviewed, the women were employed in a variety of sectors which are listed below in Table 1:

\section{Take in Table 1}

The thirteen architects who are employed in a practice are salaried and represent the 'historical' model of career within an organisation and the three employed in the public sector are to a certain extent also following the traditional notion of career but while they are employed within an organisation, they enjoy a much higher degree of time flexibility than their counterparts in practices. The nine sole practitioners, six principals and two labour-only sub-contract architects represent an alternative career path in that there is 
“independence from, rather than dependence on, traditional career arrangements” (Arthur and Rousseau, 1996:6) and "people will identify themselves more with their work than any particular organisation” (Mirvis and Hall 1996:250). While principal of a practice (or company director, depending upon the legal basis of the organisation) is the highest position that can be achieved within the profession, what is noteworthy here is that only one has achieved this position via the traditional career pathway, the remainder have established their own practices highlighting the lack of 'formal' career structures.

As a starting point explanations were sought to account for the diversity of the interviewees in the construction of the career. The women were asked about their career plans from when they chose architecture as a profession and career life histories were constructed. Contrary to the notion that a career comprises a sequence of planned, rational events the choice of architecture as a career appeared to happen more as a response to inherent reasons than as a rational objective decision. The majority reported that architecture was all they had ever wanted to do from early childhood or were influenced by family or friends working within the construction industry:

It's a very basic instinct - it goes back to age about seven when I built a wigwam in the garden with sticks and string and leaves. I only wanted to do architecture because I wanted to know how the buildings around me worked (Jennifer: salaried architect)

It's something I felt drawn to, really. I didn't know anybody who was an architect, I always liked trying to draw things, I designed a doll's house when I was a child. It was just something I was drawn towards (Amanda: labour-only sub-contract)

I wanted to work in the building industry. I didn't know there were such things as architects actually. I come from a working class background ... my dad was a navvy on a building site (Marlene: salaried architect) 
A key feature which emerged was the apparent lack of planning which followed the initial choice of profession. Only two of the women reported that they had any sort of idea about how they wanted their careers to progress and both wanted to work for themselves rather than for a practice. For several others the emphasis was on creating a structured career path for their husbands. Their own career was going to be secondary, in spite of them having qualified in a high status and demanding profession, reflecting the different levels of accommodation of male and female careers (Gutek and Larwood, 1989) and the role of the wife in supporting the husband's career (Kanter, 1977; Marshall and Cooper, 1976). The career paths of the others progressed as a response to the constraints and opportunities which presented themselves at various times:

It sounds terrible, it is terrible to me now but I didn't really think about what kind of work do I want to do [or] where am I going to go to get it sorted out ... I mean the career plan at that stage was my husband's (Alex: university lecturer)

I mean a career has actually got to have some sort of game plan, a strategy. I haven't got that, I ought to have it (Michelle: sole practitioner)

Very few of the women interviewed had much of a career plan, at least not in anything other than vague terms. However, given that careers are subject to influences from all areas of life, many of which are unforeseen, subject to both planned and unplanned events and so the career cannot be considered as a separate independent entity. The notion of career as a series of ordered and planned experiences is a myth as it does not allow for the interaction of unplanned everyday experiences (Höpfl and Hornby-Atkinson, 2000). 
In turn, this is a positive evaluation in relation to women's careers as "women have long been aware of the problems associated with a unitary notion of organisational commitment” (Höpfl and Hornby-Atkinson, 2000:140).

Where choice and preference influenced the construction of the career, reasons given were mainly concerned with issues regarding control over the career and quality of life with a need to combine family and career mentioned but only given as the primary reason in two cases. However, in other cases the working arrangements came through necessity as a response to the difficult economic conditions present in the UK construction industry during a large part of the 1990s.

\section{Ownership and Control of Career:}

Control over their career especially in terms of being able to organise their own time and work appeared to be an important feature for those working in a non-standard sense. The interview data indicates that working time and the freedom to control the level of engagement with work are the key differences between those who follow the traditional career path and those who have adopted an alternative architectural career.

The satisfying bit is not being told what to do by anybody ... doing what is pleasant, earning money that's your own (Rachel: principal of practice)

... I have in the past worked very long hours ...[but] there's more to life than work and I'm in a position where I don't have to work so hard and I can try and do what is enjoyable rather than slog my heart out. (Rita: sole practitioner) 
I want to succeed as an architect, I enjoy architecture and I feel I ought to be able to work on it the hours that I want to. It [self-employment] has been very good for me architecturally and from the point of view of being able to organise my time (Sandra: sole practitioner)

You work when the work is there and do it to suit yourself. It's very flexible being in the position that we're in ... I'm probably a bit more in charge of my own destiny being in this position (Ellen: company director)

[My career has] been better since I became self-employed ... I think for women to be self-employed you are in control of your own career and I find it much more pleasant. (Rita: sole practitioner)

Closely related to quality of life issues is the need to have control over both working time and their own future in contrast to the 'traditional' form of career in which the organisation took charge of progression and effectively 'owned' the career.

The positive side is that working for yourself, I'm quite happy to work 14 hours a day and through the weekend, which I can do because I don't have a family, and then I'll just bog off for four days. I've never been very good at nine to five, I'm terrible at getting up in the morning and I much prefer managing my own time (Helen: principal of practice)

[I work] 75 hours [a week] but that's mainly because it's partly my business now, I'm working for my future and my company's future (Sarah: company director)

These comments contrast starkly with remarks made by the salaried architects:

You're always expected to do overtime, always ... unpaid but expected, it's general for everybody, it's not whether you're male or female ... you just do it. (Lindsey: salaried architect)

I've been having appalling morning sickness and get very tired ... I've just had to say it's 5.30 and I can't do anything else because I'm shattered ... I still have to get up at six in the morning to go on site or whatever ... I'll still be there to do my job wholeheartedly but at the same time you can't jeopardise your pregnancy (Loren: salaried architect) 
Before I went on holiday I was nearly losing my mind, I'd worked 18 days on the trot, we worked two whole weekends and three whole weeks before I collapsed ... I'd be there 'til nine at night ... we'd not even get a proper lunchbreak ... I worked it out last year I worked out I did 300 hours overtime, unpaid... I made myself ill as well ... there was just no reprieve (Marlene: salaried architect)

In contrast to those who considered the benefits of quality of life and control over their career to be important, the salaried architects found that the organisational requirements regarding working time to be excessively demanding. Many employers now expect unpaid overtime to be carried out as a matter of course. Long hours have become an integral and accepted part of the culture of being employed as a salaried architect as well as in many other professions in order to demonstrate greater commitment (Noon and Blyton, 1997; Kanter, 1977; Fink, 1992). The periods of economic and employment uncertainty, which have prevailed in the architecture profession and construction industry, have created a climate where it is necessary to demonstrate high commitment and, to some extent, 'presenteeism' for the salaried architects. The principals of practices and sole practitioners report having the greatest amount of control over the amount of time they spend working and the amount of work they carry out.

\section{Family:}

Only two of the twenty cited family reasons for not following a traditional career path, these are both sole practitioners working on a small scale basis but wanting to keep in touch with the profession and to be able to work on their own terms: 
I don't particularly want to work as a self-employed architect. I like the work environment because I enjoy the company of other people, I enjoyed that part of the office whereas on my own sitting at my drawing board in my study, I keep looking for excuses to be doing something else [but] if I'm going to work from home it's going to be something that my skills can be used for (Geraldine: sole practitioner)

I really wanted to be at home with the children [but] I did need the stimulus of a job ... so it just seemed right that if people asked me to do a job, I could do it around the children so it just gradually built up ... and it's just gone on since then. (Stephanie: sole practitioner)

These women do not 'fit' with Hakim's (2000) definition of 'work centred' but while they are 'home centred' to some extent, they are also 'adaptive' in that they want to combine both work and family activities. This does not mean that they are any less committed to their work and career than their counterparts who have continued to work full-time as well as raising children. In fact, it could be argued that they are more committed because they are adapting their working lives to take both spheres of activity into account:

We're not just doing this [architecture] to fill in time ... we need something more ... our profession has to realise we do things a bit differently but that doesn't mean we do them wrong or that we're not going to be contributing. (Geraldine: sole practitioner).

She goes on to say:

Our profession is changing and in many ways we're perhaps ahead of it, in that we're changing to adapt to it before it has happened ... the more versatile we are the better chance we stand. We have to exploit the multi-faceted role, and perhaps women going off in slightly different ways are showing the way. Women have had to realise that we have lots of different skills and we have to use different skills at different stages in our career, as our careers change... ... but it just suddenly makes you think the traditional career course isn't really for you if you've got kids, you've got to juggle it a little bit and it's finally sunk in that my career will progress under my own steam. (Geraldine: sole practitioner). 
This shows an awareness of the fact that the traditional career path is changing (Young and Collin, 2000; Patton, 2000; Doyle, 2000) as well as the fact that women have had to adapt their careers to take families and home responsibilities into account. In addition, it supports the view that women are less afraid than men of trying something alternative or non-standard and are willing to develop their careers differently (Moore and O’Neill, 1996; Hakim, 1996).

\section{Economic conditions:}

The construction industry is one of the most vulnerable sectors in relation to changes in the economy. The industry is dependent upon the economic health and strength of other sectors for its own wellbeing (Sinden, 1998). The recession which impacted upon the construction industry during the 1990s caused a large number of redundancies among architects and self-employment became a viable option as a means of career survival. Nine of the 37 interviewed were made redundant and of these, three experienced redundancy twice. Of the nine, two found employment within two months, four were practising as a sole practitioner, another had started as a sole practitioner but her practice had grown and she now has four employees, two were employed on a labouronly subcontract basis and have the least amount of control over their working lives and, correspondingly have the lowest security of employment. They are dependent upon whether the practices that they work for have sufficient work for them. In the event of a fall in the practice workload they would be unemployed with little or no notice and, because of being self-employed, would not be eligible for unemployment benefit. 
Self-employment as a result of redundancy exists as a response to external conditions and while it had not been an original career choice, it has enabled the women to remain in the profession and progress their careers in a different way.

[I] was made redundant in March 1991 ... and by the following Spring, I'd been doing bits and pieces, I thought I'd try and make a go of it myself. I was made redundant on the understanding that they'd take me back on when work picked up but of course, it never did. So that's been it, so I've been on my own since 1992 (Denise: sole practitioner/university tutor/part-time draughting work)

Denise has more of a portfolio working life rather than just surviving purely on selfemployed work. She teaches a Masters level Module on Conservation at a local School of Architecture which she got as a result of studying for the degree herself and also has a part-time draughting job for a local firm:

The three jobs I have are interconnected ... if I hadn't been working at [the draughting job] I wouldn't have done the MA, if I hadn't done the MA I wouldn't have got the teaching work, if I wasn't also in private practice I wouldn't have got the teaching work. If I had only been working at [the draughting job] I wouldn't have had the opportunity to make money. It's a good earner doing their work, it's easy work so all three really are interconnected. There's a standard amount coming in every month, I can depend on it and I can choose my time of working. I just tell them when I'm going in and the money covers the overheads of my own practice (Denise: sole practitioner/university tutor/part-time draughting work)

For Melissa the decision to become self-employed after redundancy was based on the fact that she is unable to work full-time due to ill-health and part-time work within a practice in architecture is virtually non-existent (Hakim, 2000):

About five years ago I was made unemployed and I could only work part-time because of health problems and part-time work is almost non-existent ... the alternative was to work for myself (Melissa: sole practitioner) 
A significant factor, aside from these, which features strongly in decisions to become self-employed must be the fact that architecture is project-based and that, even in times of recession, small-scale projects can contribute towards an income. Much work is based on word of mouth or gained through personal contacts and there is a relatively strong informal market for architectural services. A further advantage is that it can be done from home thus keeping overheads to a minimum.

\section{Conclusions}

Previous research has concentrated on the 'standard' career structures within professions. However, the extent to which the women interviewed have rejected this traditional career path must be considered significant. The reasons and factors affecting and causing this decision must be taken in to account. It could be that the 'traditional' career in architecture does not allow the flexibility necessary to juggle the demands of pursuing a demanding professional occupation with the demands of a family and as such, these alternatives forms of work exist as a form of 'feminsation' (Crompton and Sanderson, 1990). Secondly, it could be because the architecture profession and more widely, the construction industry are so male-dominated that women are effectively excluded from the traditional career structures (Spencer and Podmore, 1987; Kanter, 1977; Crompton and Sanderson, 1990; Evetts, 1994).

There is a paucity of studies which examine the experiences of men in relation to these findings so it is inappropriate to make comparisons between male and female careers. 
However, the employment patterns and career paths of these female architects shows how working lives can be successfully adapted to incorporate personal preference as well as to respond to environmental and economic conditions - findings which may also be relevant to male careers and also to other professions. Within the construction industry and property sector in recent years, there has been a great deal of employment insecurity and these careers show how this has been taken into account. In addition, a rather paradoxical situation results, in that the nature of employment within the construction industry is appropriate for the adoption of flexible forms of working, with work being project-based, but the construction industry is traditionally male-dominated and while evidence indicates that men are less oriented towards alternative forms of working (Hakim, 1995), few explanations have been offered as to why this maybe the case. The level of satisfaction with work reported by those women who have adopted alternative forms of working much be considered significant especially when compared with the extent of the dissatisfaction expressed by their counterparts on the more 'traditional' career ladder.

The women interviewed comprised a relatively homogeneous group, in that they have all achieved the training and qualifications necessary for membership of the professional body for architects, the RIBA. As such, it could be surmised that because this level of investment in their human capital they would display a high level of commitment to their career demonstrated by following the 'traditional' career path with its emphasis on fulltime work and an upward, linear progression within an organisation. However, as the research has indicated this is not the case. Less than half of those interviewed have chosen 
this route and invariably express feelings of dissatisfaction over long working hours and lack of autonomy. Those who have adopted more 'non-standard' careers report greater levels of satisfaction in that they feel they have ownership and control over their career. The norms regarding career paths in terms of an upwardly linear progression within an organisation are becoming less distinct and there is a move from the 'bounded' career to the 'boundaryless' career with greater emphasis on 'organising' rather than the ‘organisation’ (Littleton et al, 2000).

The different forms of career shown by these women represent an alternative way in that women can succeed. As Doyle states “... orthodox career management models and structures are struggling to adapt and cope with what it becoming an increasingly complex, diverse and fluid organisational context” (Doyle, 2000:229), the same can be said to apply to the external environment. Just as organisations are operating in increasingly complex environments, individuals have many more options open to them and constraints placed upon them and can be considered as 'stakeholders' in their own career (Doyle, 2000).

The diversity in career paths displayed reflects a move away from the idea that career management means progression upwards through the organisation and towards the individual developing their own professional life in order to achieve a wider range of objectives. It also shows how the career can be successfully adapted to take into account the events which co-exist in the lives of individuals. Prior research into the concept of career assumes that the career 'stands alone' in some sort of predetermined way with a 
sequence of planned outcomes throughout its life cycle. This research indicates that this is not the case - it is the interaction of a multiplicity of differing factors planned and unplanned, internal and external to the individual and their lives. The key feature being the 'ownership' of the career belonging to the individual instead of the organisation.

\section{References}

Adams, A. and Tancred, P. (2000) Designing Women: Gender and the Architectural Profession. Toronto, University of Toronto Press.

Arthur, M.B. and Rousseau, D.M. (eds) (1996) The Boundaryless Career: A New Employment Principle for a New Organisational Era, Oxford, Oxford University Press.

Bruegel, I (1996) 'Whose myths are they anyway?: a comment.' British Journal of Sociology 47, 1, March, 175-177.

Caven, V. (1999) Career Building: Women at Work in the Architecture Profession. Unpublished PhD thesis, University of Nottingham.

Crompton, R. and Sanderson, K. (1990) Professional Women’s Careers in McRae, S. (ed) Keeping Women In. London, Policy Studies Institute.

Crompton, R. and Le Feuvre, N. (1996) Paid Employment and the Changing System of Gender Relations: a Cross-National Comparison. Sociology. 30, 3.

Crompton R. and Harris, F. (1998) Explaining Women's Employment Patterns: 'Orientations to Work Revisited'. British Journal of Sociology, 49, 1.

De Graff-Johnson, A., Manley, S. and Greed, C. (2003) 'Why do women leave architecture?'. RIBA/University of West of England Research Project. London, RIBA.

Doyle, M. (2000) Managing Careers in Organisations in Collin, A. and Young, R.A. (eds) The Future of Career. Cambridge, Cambridge University Press.

Epstein, C.F., Seron, C. Oglensky, B. and Saute, R. (1999) The Part-Time Paradox: Time Norms, Professional Life, Family and Gender. New York, Routledge.

Evetts, J. (1994) 'Women and Career in Engineering: continuity and change in the organisation’. Work, Employment and Society, 8, 1, 101-112

Fink, S.L. (1992) High Commitment Workplaces. New York, Quorum. 
Franz N.A. (1965) English Women enter the Professions. Cincinnatti, Ohio. Colombia University Press.

Ginn, J. Arber, S. Brannen, J. Dale, A. Dex, S. Elias, P. Moss, P. Pahl, J. Roberts, C. and Rubery, J. (1996) 'Feminist Fallacies: a reply to Hakim on women's employment.' British Journal of Sociology 47, 1, 167-174.

Gutek, B.A. and Larwood, L. (eds) (1989) Women’s Career Development. Newbury Park, Ca., Sage.

Hakim, C. (1995) 'Five Feminist Myths about Women's Employment.' British Journal of Sociology, 46, 3, 429-455.

Hakim, C. (1996) Key Issues in Women's Work: Female Heterogeneity and the Polarisation of Women's Employment. London, The Athlone Press.

Hakim, C. (1998) 'Developing a Sociology for the Twenty-First Century: Preference Theory’. British Journal of Sociology. 49, 1,137-143.

Hakim, C. (2000) Work-Lifestyle Choices in the $21^{\text {st }}$ Century. Oxford, Oxford University Press.

Höpfl, H. and Hornby Atkinson, P. (2000) The Future of Women's Career in Collin, A. and Young, R.A. (eds) The Future of Career. Cambridge, Cambridge University Press.

Kanter, R.M. (1977) Men and Women of the Corporation. New York, Basic Books.

Lewis J. (1998) Put your Daughter on the Stage. Building Design $1^{\text {st }}$ May.

Littleton, S.E. Arthur, M.B. and Rousseau, D.M. (2000) The Future of Boundaryless Careers in Collin, A. and Young R.A. (eds) The Future of Career. Cambridge, Cambridge University Press.

Mallon, M. and Cohen, L. (2001) 'Time for a Change? Women's Accounts of the Move from Organisational Careers to Self-Employment' British Journal of Management, 12, 217-230.

Marshall, J. and Cooper, C.L. (1976) 'The Mobile Manager and His Wife' Management Decisions, 14: 179-225.

Melvin J. (1997) 'Just Retribution for Professional Bias.’ Architects Journal. June 19th.

Mirvis, P.H. and Hall, D.T. (1996) Psychological Success and the Boundaryless Career in Arthur, M.B. and Rousseau, D.M. (1996) The Boundaryless Career: A New Employment Principle for a New Organisational Era. Oxford, Oxford University Press. 
Moore, B. and O’Neill, D. (1996) The Impact of Redundancies on Local Labour Markets and the Post Redundancy Experience. London, HMSO.

Nicholson, N. and West, M. (1989) 'Transitions, Work Histories and Careers' in Arthur M.B., Hall D.T. and Lawrence B.S. (eds) Handbook of Career Theory. Cambridge, Cambridge University Press.

Noon, M. and Blyton, P. (1997) The Realities of Work. Basingstoke, Macmillan.

Patton, W. (2000) Changing Career: the Role of Values in Collin, A. and Young, R.A. (eds) The Future of Career. Cambridge, Cambridge University Press.

Procter, I. and Padfield, M. (1999) ‘Work Orientations and Women’s Work: A Critique of Hakim's Theory of the Heterogeneity of Women'. Gender, Work and Organization, 6, 3, 152-162.

Royal Institute of British Architects (2003) Survey of Employment and Earnings. London, RIBA.

Shaw, S., Taylor, M. and Harris, I. (2000) 'Jobs for the Girls: a Study of the Careers of Professional Women Returners following participation in a European funded updating programme’. Career Development International 5/6, 295-300.

Sinden, A (1998) 'Employment Decline in the UK Architecture and Surveying Sectors' The Service Industries Journal. 18, 1.

Spencer, A. and Podmore, M. (1987) In a Man's World: Essays on Women in Maledominated Professions. London, Tavistock Publications.

Sullivan, S.E. (1999) 'The Changing Nature of Careers: A Review and Research Agenda', Journal of Management, 25, 3, 547-584.

Walker, L. (1989) Women Architects in Attfield J. and P. Kirkham (eds) A View from the Interior: Feminism, Women and Design. London, The Woman's Press.

Walsh, J. (1999) 'Myths and Countermyths: An Analysis of Part-Time Female Employees and Their Orientations to Work and Working Hours'. Work, Employment and Society June, 13, 2, 179-203.

Young, R.A and Collin, A. (2000) Introduction: Framing the Future of Career in Collin, A. and Young, R.A. (eds) The Future of Career. Cambridge, Cambridge University Press.

Young, E. (2003) ‘Running to Stand Still’ RIBA Journal, July. 
Table 1: Sectors of Employment

\begin{tabular}{|l|l|}
\hline Sector of Employment & No \\
& $(\mathrm{n}=37)$ \\
\hline Employee in practice & 13 \\
\hline Employed in Public Sector & 3 \\
\hline Sole Practitioner & 9 \\
\hline Principal of Practice & 6 \\
\hline Labour Only Self-employed & 2 \\
\hline Retired & 2 \\
\hline Career Break & 1 \\
\hline Unemployed & 1 \\
\hline
\end{tabular}

